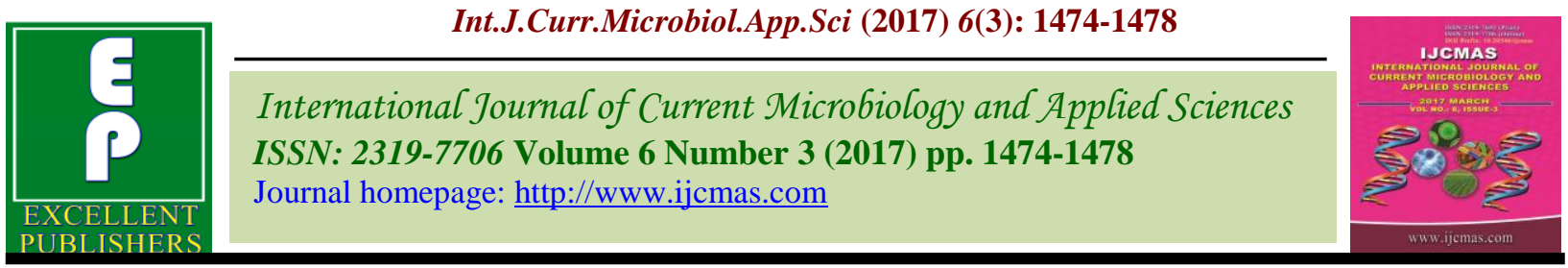

Original Research Article

https://doi.org/10.20546/ijcmas.2017.603.169

\title{
Pesticide Residues in Some Types of Spices Collated from Libyan Market
}

\author{
N. Essawet ${ }^{1}$, H. Abushahma ${ }^{2}$, S. Inbaia ${ }^{1^{*}}$ and H.A. Amra ${ }^{3}$ \\ ${ }^{1}$ Azzaytuna University-Libya, \\ ${ }^{2}$ Higher Institute of Agriculture Techniques, Al-Ghiran-Libya \\ ${ }^{3}$ National Research Center, Egypt \\ *Corresponding author
}

\author{
A B S T R A C T
}

\section{Ke y w o r d s \\ Pesticide residues, \\ Spices, \\ Organochlorine, \\ Organophosphorus. \\ Article Info \\ Accepted: \\ 22 February 2017 \\ Available Online: \\ 10 March 2017}

The investigation aimed to study the contamination of locally marketed spices in Tripoli (caraway, cumin, cinnamon, mixed spices, black pepper, and red pepper) during (2014). Sixty samples of various kinds of spices were extracted and determined for residues of organophosphorus (malathion, methylparathion, parathion, carbo-phenothiate and ethion) and organochlorine pesticides (aldrin, BHC, heptachlore, lindane, DDT, endrin, heptachlor epoxide and dieldrin).The obtained results demonstrated that organophosphorus pesticides were not detected in all of the analyzed samples except for ethion which was found in concentration of $(2.3 \pm 0.03,4.5 \pm 0.09,0.9 \pm 0.01,1.9 \pm 0.05,1.4 \pm 0.07$, and $2.7 \pm 0.08 \mu \mathrm{g} / \mathrm{kg})$ in caraway, mixed spices, cinnamon, black pepper, cumin and red pepper, respectively. While the residues of some organochlorine pesticides (aldrin, lindane, endrin and dieldrin) were $1.57 \pm 0.04,0.8 \pm 0.08,2.1 \pm 0.02$ and $10.76 \pm 0.1 \mu \mathrm{g} / \mathrm{kg}$ in caraway, respectively; $2.1 \pm 0.4,3.4 \pm 0.07,1.8 \pm 0.09$ and $2.3 \pm 0.1 \mu \mathrm{g} / \mathrm{kg}$ in mixed spices, respectively; $3.45 \pm 0.07$, $1.2 \pm 0.01,2.41 \pm 0.05$ and $2.57 \pm 0.03 \mu \mathrm{g} / \mathrm{kg}$ in cinnamon, respectively; $3.1 \pm 0.03,2.75 \pm 0.3$, $1.96 \pm 0.09$ and $1.3 \pm 0.7 \mu \mathrm{g} / \mathrm{kg}$ in black pepper, respectively; $1.4 \pm 0.08,2.8 \pm 0.01,1.4 \pm 0.07$ and $1.2 \pm 0.03 \mu \mathrm{g} / \mathrm{kg}$ in red pepper, respectively; $7.6 \pm 0.1,12.1 \pm 0.09,9.8 \pm 0.1$ and $10.2 \pm 0.2$ $\mu \mathrm{g} / \mathrm{kg}$ in cumin, respectively. However, residues of BHC, heptachlore, total DDT and heptachlore epoxide were not detected.

\section{Introduction}

Spice, a major group of the food additives is a vegetable substance of indigenous or exotic origin which is or has a hot, pigment taste, used to enhance taste of foods or to add to them the stimulant ingredients contained in them (Adamson, 2004).

Spices and medicinal plants are widely used as raw materials for pharmaceutical preparations (Galenic products) and as a supplement for dietetic products and especially for "self medications" in the general population. These plants are susceptible to insect and disease attacks, so pesticides are widely used for protection. Therefore, residues of pesticides could reach and affect consumers especially when they are freshly consumed. Pesticide residues in food have historically lagged far behind many comparable hazards as a cause for public health concern and action (Correia et al., 2000; Eskenazi et al., 2008). Pesticide residue contaminating food is the problem focused worldwide because of its direct implications on human health and international trade (Sanborn et al., 2004). 
Pesticides belong to substances which are the most toxic and are persistent; they do not break down easily, have ability to bioaccumulate, and can be mobile in the environment. They can also become mutagenic, carcinogenic, teratogenic, and allergenic. Pesticides can enter an organism through the digestive system, and even small amounts can be harmful if their intake lasts longer (Kroes et al., 2000; Gorrido et al., 2003). Many studies have been carried out in different countries on spice and medicinal plants. In Germany, it was reported that the residues of DDT and its derivatives, $\mathrm{HCH}$, dimethoate, and parathion methyl predominated as contaminants.

On the other hand, DDT, $\mathrm{HCH}$, aldrin, dieldrin, and heptachlor were detected in different samples collected from India. Organophosphorus pesticides are widely used in agriculture and animal production for the control of various insects. These compounds have higher acute toxicity than chlorinated pesticides and they have the advantage of being more rapidly degraded in the environment. Organochlorine pesticides, which 20 years ago were being used in Egypt, are highly persistent.

\section{Materials and Methods}

Sixty samples of crushed spices (caraway, mixed spices, cinnamon, black pepper, red pepper and cumin) were collected from private markets at Tripoli city (Table 1). Samples were collected randomly and put into cellulose paper bags. Sample weight at collection was 100- $200 \mathrm{~g}$ and information about sample name, weight and date of collection were recorded on each bag. Samples were transferred under suitable conditions for storage and stored at $4-20{ }^{\circ} \mathrm{C}$ until tests were carried out to assess the residues of organochlorine and organophosphorous pesticides.
The residues of organochlorine and organophosphorous pesticides were detected and assessed in the present research according to AOAC (2000) method for dried foods. Samples were prepared for laboratory examination by taking $25 \mathrm{~g}$ subsamples, extraction with acetonitril: water (65:35) mixture, the filtration through Whatman no 4 filter paper, measuring the filtrate volume and liquid-liquid partition with petroleum ether solvent. Separation column was prepared with Florasil and elution with petroleum ether and diethyl ether solvents. Injections were carried out on a gas chromatograph with the following technical specifications:

Gas chromatograph- varian 3700 with pulse modulated $63 \mathrm{Ni}$ electron capture detector (ECD) $\left(280^{\circ} \mathrm{C}\right.$ amplifier range 10) and heated bead alkali flame ionization detector (AFID) $\left(250{ }^{\circ} \mathrm{C}, 10-11 \mathrm{~A}\right.$ range $)$. Nitrogen carrier gas flow rate $30 \mathrm{ml} / \mathrm{min}$, injector temperature 190 ${ }^{\circ} \mathrm{C}$, column temperature $190{ }^{\circ} \mathrm{C}, 9$ min then programmed $40{ }^{\circ} \mathrm{C} / \min$ to $230{ }^{\circ} \mathrm{C}$.

\section{Results and Discussion}

The results demonstrated that the assessed residues of the organophosphorous pesticides i.e. malathion, methyl parathion, parathion and carbophenothion were under the detection level of the apparatus except for ethion pesticide where the average maximum concentration was $4.5 \pm 0.09 \mu \mathrm{g} / \mathrm{kg}$ in the samples of mixed spices and the minimum concentration was $0.9 \pm 0.01 \mu \mathrm{g} / \mathrm{kg}$ in cinnamon samples (Table 2).

Table 3 shows the results of the organochlorine pesticides residues, where the highest average concentration was $3.1 \pm 0.03$ $\mu \mathrm{g} / \mathrm{kg}$ for aldrin in the samples of the black pepper and the lowest was $0.45 \pm 0.07 \mu \mathrm{g} / \mathrm{kg}$ in cinnamon samples. 
Table.1 The common and scientific names of spices that sampled from private markets

\begin{tabular}{|c|c|}
\hline Common name & Scientific name \\
\hline Caraway & Carum carvi L. \\
\hline Mixed spices & Eucalyptos globulus L. \\
\hline Cinnamon & Cinnamonum verum Presel \\
\hline Black pepper & Piper nigrum L \\
\hline Red pepper & Capsicum frutescens L. \\
\hline Cumin & Cuminum cuminum \\
\hline
\end{tabular}

Table.2 Average concentrations of organophosphorus pesticide residues in spices

\begin{tabular}{|c|c|}
\hline \multirow[t]{2}{*}{ Sample } & $\begin{array}{c}\text { Average concentration of organophosphorus pesticide } \\
\text { residues, } \\
\mu \mathrm{g} / \mathrm{kg}\end{array}$ \\
\hline & $\begin{array}{l}\text { Ethion } \\
\end{array}$ \\
\hline Caraway & $2.3 \pm 0.03$ \\
\hline Mixed spices & $4.5 \pm 0.09$ \\
\hline Cinnamon & $0.9 \pm 0.01$ \\
\hline Black pepper & $\mathbf{1 . 9} \pm \mathbf{0 . 0 5}$ \\
\hline Cumin & $1.4 \pm 0.07$ \\
\hline Red pepper & $2.7 \pm 0.08$ \\
\hline
\end{tabular}

Table.3 Average concentrations of organochlorine pesticide residues in spices

\begin{tabular}{|l|l|l|l|l|l|l|}
\hline Pesticides & Caraway & Cumin & Cinnamon & $\begin{array}{l}\text { Mixed } \\
\text { spices }\end{array}$ & $\begin{array}{l}\text { Black } \\
\text { pepper }\end{array}$ & $\begin{array}{l}\text { Red } \\
\text { pepper }\end{array}$ \\
\hline Aldrin & $1.57 \pm 0.04$ & $7.6 \pm 0.1$ & $3.45 \pm 0.07$ & $2.1 \pm 0.4$ & $3.1 \pm 0.03$ & $1.4 \pm 0.08$ \\
\hline Lindane & $0.8 \pm 0.08$ & $12.1 \pm 0.09$ & $1.2 \pm 0.01$ & $3.4 \pm 0.07$ & $2.75 \pm 0.3$ & $2.8 \pm 0.01$ \\
\hline Endrin & $2.1 \pm 0.02$ & $9.8 \pm 0.1$ & $2.41 \pm 0.05$ & $1.8 \pm 0.09$ & $1.96 \pm 0.09$ & $1.4 \pm 0.07$ \\
\hline Dieldrin & $10.76 \pm 0.1$ & $10.2 \pm 0.2$ & $2.57 \pm 0.03$ & $2.3 \pm 0.1$ & $1.3 \pm 0.7$ & $1.2 \pm 0.03$ \\
\hline
\end{tabular}




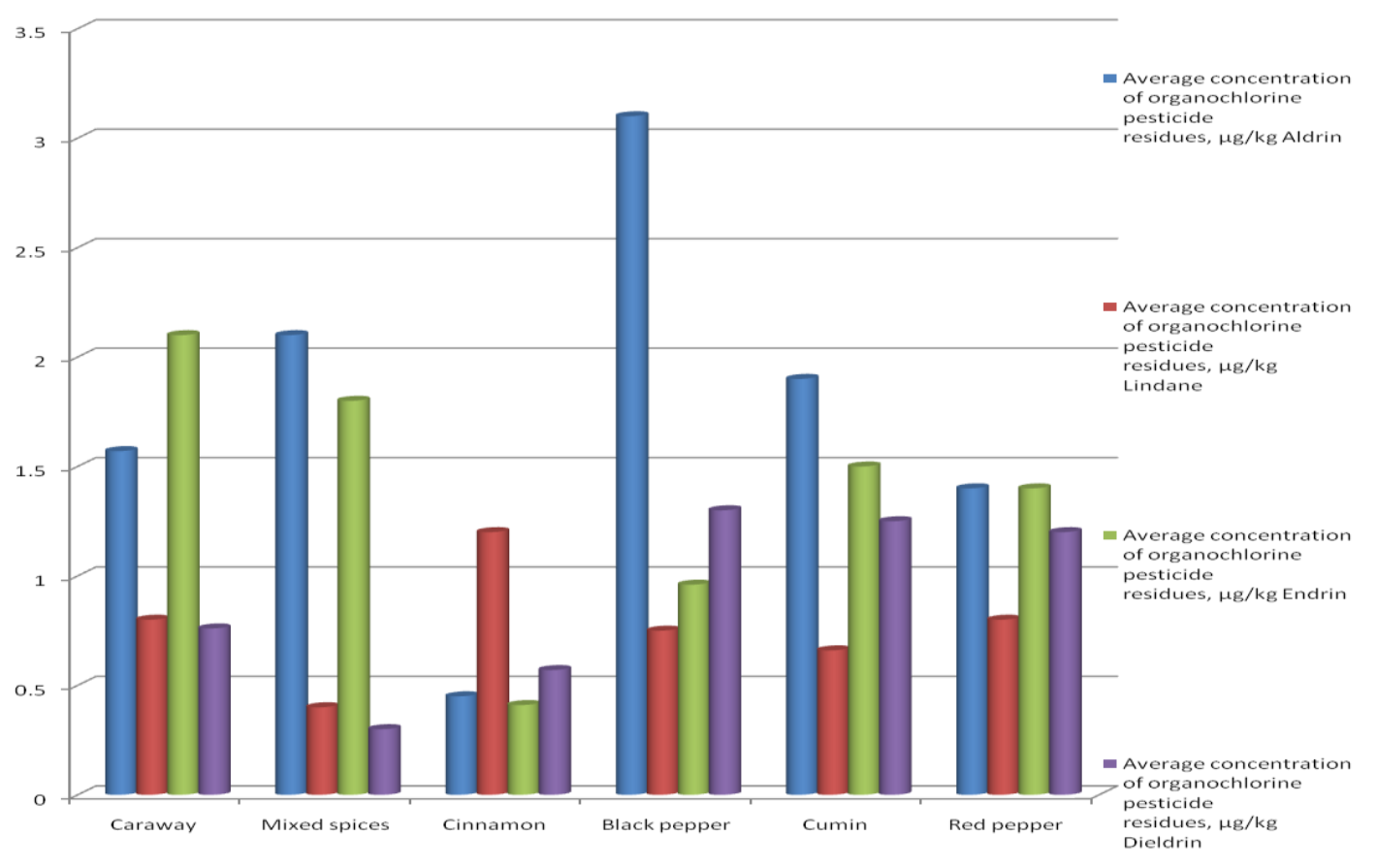

The highest average concentration for Lindane $(1.2 \pm 0.01 \mu \mathrm{g} / \mathrm{kg})$ was found in cinnamon samples and the lowest $(0.4 \pm 0.07$ $\mu \mathrm{g} / \mathrm{kg}$ ) was in mixed spice samples. Endrin highest average concentration $(2.1 \pm 0.02$ $\mu \mathrm{g} / \mathrm{kg}$ ) was found in caraway samples and the lowest $(0.41 \pm 0.05 \mu \mathrm{g} / \mathrm{kg})$ in cinnamon samples. The maximum average concentration of dieldrin $(1.3 \pm 0.079 \mu \mathrm{g} / \mathrm{kg})$ was found in the samples of black pepper and the minimum $(0.3 \pm 0.1 \mu \mathrm{g} / \mathrm{kg})$ in mixed spice samples.

Azanu (2014) found that residue of organochlorine pesticides are present in spices in Ghana with concentrations lower than their maximum recommended residue levels. Although these residues occurred at very low concentrations in the samples, they may accumulate to higher levels in human beings who consume these products. The results will help in a scientific assessment of the implications of pesticide residues with regards to human risks.

\section{References}

Adamson, M.W. 2004. "Food in Medieval Times". ISBN 0-313-32147-7.

AOAC. 2000. Methods of Analysis, (16th ed.), Pesticide and industrial chemical residues, (Chapter 10, 16th ed, pp. 1士78), Association of official Analytical Chemist (AOAC), Washington, D.C. Arlington: AOAC.

Azanu, D., Mike, A., Acheampong and Martin, Y., Woode. 2014. Heavy Metals and Organochlorine Pesticides Residue Levels in Natural Spices Sold in Kumasi, Ghana, Int. J. Environ. Sci. Toxicol. Res., 2(6): 130-135.

Bann, J.M. 1957. A Review of residue analysis methods for the determination of aldrin, dieldrin, endrin and phosdrin insecticide. Memoshell chemical Corp., York. N.T.

Correia, M., Delerue-Matos, C. and Alves, A. 2000. Multi-residue methodology for pesticide screening in wines. Chromatography A, 889: 59-67. 
Dogheim, S.M., Almaz, M.M., Takia, N.S., and Youssef, A. 1986. Multiple analysis of pesticide residues in certain plants of medicial importance. Bull. Entomol. Soc. Egypt, Economic, 15: 157 \pm 163 .

Eskenazi, B., Rosas, L.G., Marks, A.R., Bradman, A., Harley, K., Holland, N., Johnson, C., Fenster, L. and Barr, D.B. 2008. Pesticide toxicity and the developing brain. Basic and Clin. Pharmacol. Toxicol., 102(2): 228-236.

Gorrido, F., Martinez, V.J.L., Moreno, F.M., Olea, S.F., Cuadros, R.I. 2003. Determination of organochlorine pesticides by GC-ECD and GC-MS-MS techniques including an evaluation of the uncertainty associated with the results. Chromatographia, 57(3/4): 213-220.
Kroes, R., Galli, C., Munro, I., Schilter, B., Trans, L.A., Walker, R. 2000. Threshold of toxicological concern for chemical substances present in the diet: a practical tool for assessing the need for toxicity testing. Food and Chem. Toxicol., 38: 255-312.

Nerd'in, C., Battle, R., Sartaguda, M. and Pedroch 'I, C. 2002. Supercritical fluid extraction of organochlorine pesticides and some metabolites in frogs from National Park of Ordesa and Monte Perdido, Anal. Chim. Acta, 464: 303.

Sanborn, M., Cole, D., Kerr, K., Vakil, C., Sanin, L.H. and Basil, K. 2004. Systematic Review of Pesticides Human Health Effects. The Ontario, College of Family Physicians.

\section{How to cite this article:}

Essawet, N., H. Abushahma, S. Inbaia and Amra, H.A. 2017. Pesticide Residues in Some Types of Spices Collated from Libyan Market. Int.J.Curr.Microbiol.App.Sci. 6(3): 1474-1478. doi: https://doi.org/10.20546/ijcmas.2017.603.169 